\title{
'We are taught to act': Hustling on the move in Kampala and Nairobi
}

\author{
William Monteith, Queen Mary University of London \\ with George Mirembe
}

\begin{abstract}
This article explores the question of what happens when highly socialised and contingent forms of provisioning go wrong, and young men are forced to start again in unfamiliar urban contexts. The decline of George Mirembe's moneylending business in Kampala pre-empted his departure from the country, and his arrival in Nairobi in search of new socioeconomic opportunities. Lacking the documents and language skills necessary to enter formal sectors of the economy, George claimed asylum as a sexual refugee while working as a smuggler and a voice actor in the shadow film industry. His activities illustrate the advantages and limitations of the hustle as a framework for understanding the activities of transnational 'others' in African cities. I argue that translational practices of acting and storytelling have become a generalised tactic of survival among migrants in urban East Africa. Such practices are illustrative of a form of 'uprooted hustle' - or hustling on the move - that is oriented towards individual survival and exit rather than place-based transformation.
\end{abstract}

\section{Dubbing in a world of 'doubles'}

In Nairobi, anything you do, you get money... the challenge is that you have to be Kenyan or have a work permit. l'm working undercover in the movie dubbing business, dubbing Chinese movies into Luganda at night. They usually give me hard characters; politicians, lawyers, judges, like that [laughs]... But it's good work if it's there.

December 2017

Eighteen months after his departure from Kampala, George Mirembe is upbeat about life across the border in Nairobi. Each night George makes his way from a shared house in a lowincome settlement in Kawangware to a recording studio on the outskirts of the city, via three matatu rides. On arrival, George transforms himself into Guo Youdong, a military veteran, for the Chinese action film Super Pattern. He works alongside a cast of Ugandan co-actors to translate the script from English into Luganda and record the dubbing track. The dubbed film is then sent to the Chinese media company Star Times for approval before being scheduled for release in Uganda.

George is one of a growing number of East African youth whose improvised livelihood activities, or 'hustle', has brought him into contact with the entertainment industry. The industry is one of the fastest growing in Africa, 1 in which Chinese multinationals challenge South African and Nigerian companies for access to emerging markets in Uganda and Kenya. Within this context, Nairobi has established a reputation as a digital hub, and the centre of the East African film industry. However, would-be actors and entrepreneurs from outside of Kenya must navigate the country's restrictive visa and labour regulations in order to find work. Night-time recording slots are thus preferred by operators within the 'shadow' film economy, such as George's employers, for whom the night represents an opportunity to evade some of the regulations and visa restrictions associated with daytime operation.

Dubbing, in its broadest form, involves the 'transfer' or 'translation' of information between 'one medium and another' (OED 2018). In the entertainment industry, voice actors such as George make a living by dubbing films made in Los Angeles, Mumbai and Hong Kong for audiences in video halls in Kampala and Nairobi. Narrators known as 'video jokers' (VJs) 
provide additional commentaries over the original audio track, adapting or withholding key information for comedic effect. Much like the practice of market trading, dubbing is dependent on the existence of an information asymmetry, which the 'dubber' is able to exploit through skilful acts of translation.

The etymology of 'dub' derives from 'double', which has been a source of considerable theoretical inspiration in African Studies (De Boeck and Plissart 2004; Ferguson 2006; Mbembé 2001; Simone \& Pieterse 2017). Scholars have observed the 'double' meaning of postcolonial cities, economies and institutions, and the 'lack of correspondence between what one sees and exposes, and the real value of things' (Mbembe 2001: 148). Everything has its reverse or 'shadow' side, as in the case of Nairobi's film economy. Indeed, the postcolony is itself understood as the site of the collision of different theories of value, requiring inhabitants to jump 'back and forth between one vision of the world and the other' (Newell 2012: 5, note 5 ) and to live with 'seemingly contradictory double-moves that demand counter-intuitive capacities to thrive amid frictions' (Simone \& Pieterse 2017: 155). Residents are thus required to master the art of conversion.

Conversion has long been an integral part of socioeconomic life in Africa (Guyer 2004). There has always been a profit to be made at the frontiers of different systems of value; most obviously at the geographical borders of states and kingdoms, but also at the more ephemeral boundaries of formal and informal economies. Movements across such boundaries involve the conversion of goods and currencies, but also of people. The act of conversion often involves the (temporary) transformation of the self, as different aspects of one's identity are translated between one domain and another. As George explained:

"Sometimes in life acting is needed. It is about the situation and the environment, and you act accordingly. We say in Luganda okweyisa ku Iwembeera; you act or do according to the situation you are in. We are taught to act."

April 2018

In this way, George's dramatic education began long before his arrival at the studio in Nairobi. $\mathrm{He}$ became well-versed in performative acts of translation first as a market trader and moneylender in Kampala, and then as a smuggler operating along the Kenya-Uganda border.

A substantial literature has demonstrated the significance of multiple identities and fragmented economic activities in the lives of young men and women in African cities (see e.g. Di Nunzio 2019; Honwana \& De Boeck 2005; Simone 2004; Vigh 2006) and the role of acting - or 'bluff' - in their performance (Newell 2012; Weiss 2009; Thieme 2018). However, less attention has been paid to the particular tensions that emerge between competing identities as they are performed by urban inhabitants, the ways in which these tensions are understood and managed. This article seeks to undertake such an investigation, based on the story of George Mirembe's migration from Kampala to Nairobi. George's story illustrates the ways in which translational practices of acting and storytelling are deployed in a broad variety of institutional contexts in order to enable socioeconomic advancement in conditions of adversity, extending the tactics and boundaries of the 'hustle'.

\section{Hustling on the move}

The hustle has been conceptualised as 'a localized but globally resonant condition of contemporary urbanism' based upon everyday experiences of uncertainty and 'life work' among young people in low-income settlements in Nairobi (Thieme 2018: 529). It foregrounds the experimental and improvisational activities through which Nairobi youth 'make do' and 'make meaning' in the face of a prolonged period of 'waithood' associated with low levels of formal employment and service provision (ibid; Honwana 2012). As a conceptual framework, 'hustle' consolidates key literatures on informal and 'shadow' economies (Ferguson 2006; 
MacGaffey 1991; Roitman 1990), youth and social navigation (Honwana 2012; Honwana and De Boeck 2005; Vigh 2006), global cultural imaginaries (Mains 2007; Weiss 2009), and makeshift urbanism (Parnell and Robinson 2012; Simone 2004; Simone and Pieterse 2017). Significantly, it raises pertinent questions at the interstices of these literatures on how young men and women navigate ongoing socioeconomic crises in urban African settings; the ways in which they forge meaning and connection within licit and illicit economies; and the impact of their activities on social and material infrastructures.

The analytical frame of the hustle emphasises the connection between improvised livelihood activities and vital forms of association and belonging which, although globally orientated - for example, through connections to Chinese action films, British football teams and American hip-hop artists - are rooted within particular places within the city - such as the street, the barbershop and the bar (Newell 2012; Thieme 2018; Weiss 2009). Critically, it is through this connection to place that the generative potential of the hustle is constituted. George's story therefore raises important questions about the hustle as a mode of urban African life capable of integrating transnational 'others'. How far do the tactics and vocabularies of the hustle travel across cultural and institutional boundaries? What is the role of translation in their (re)production? And to what extent do transnational migrants seek to ground their economic activities within forms of association and belonging rooted in Nairobi, as opposed to those located elsewhere?

These questions necessitate a different methodological approach to that present in many of the place-based ethnographies of urban youth in Africa (Jones 2010; Mains 2007; Newell 2012; Thieme 2018; Weiss 2009). They require a mobile, multi-sited and longitudinal approach that follows protagonists as they are ejected from particular urban environs and seek to establish themselves elsewhere. This approach brings the literature on the hustle economy into conversation with the scholarship on migration and mobility in Africa (Batterbury 2001; Cliggett 2005; Englund 2002; Landau 2006; Porter et al. 2010; 2018). Conceptualising migration as a form of 'productive bricolage' (Batterbury 2001), this scholarship has documented the long history of (predominantly young, male) migrants leaving their communities and seeking their fortune in more favourable environments, producing patterns of circular migration and debt underwritten by the harsh realities of African urban economies (James 2014; Potts 2011). Transnational migrants in Nairobi might be said then to represent a group of 'uprooted hustlers', who share many of the same strategies and imaginaries as their Kenyan counterparts, albeit with a limited investment in projects and associations grounded in Nairobi.

This article traces the movements and activities of a particular protagonist over a five-year period. In doing so, it seeks to advance debates on the hustle in three distinct ways. First, it establishes the advantages and limitations of the hustle as framework for understanding the activities of transnational 'others' in African cities. Second, it introduces the idea of the uprooted hustle as a concept that foregrounds the translational practices of acting and storytelling that reproduce the hustle as a transnational phenomenon. Third, it demonstrates the reach of these practices beyond the realm of street-based economies into the film and humanitarian industries. Taken together, these contributions demonstrate the ways in which the hustle is both a transient phase exemplifying urban economic struggle and a generative form of urban life in its own right, driven by a particular set of skills and experiences (Thieme et al., this issue).

The following sections follow George Mirembe from the time of our introduction in Nakasero market in Kampala in 2013 (see Monteith 2017; 2018) to the time of his arrival in the studio on the outskirts of Nairobi in 2018. George and I (Monteith) are of a similar age (early 30s) and have both performed numerous roles in order to make a living over the past five years. We have kept in touch via multiple channels, including face-to-face meetings, telephone conversations and social media, as a result both of our friendship and of George's 
determination to share his story as it unfolded (see Monteith 2017 for a discussion of the ethical implications of this relationship). The account presented here was generated from a total of ten face-to-face interviews and five phone interviews with George between 2015-2018, which followed a twelve-month period of ethnographic fieldwork in Nakasero. Although unsystematic, this material provides a snapshot of George's life at several critical junctures.

Through its emphasis on the story of a single protagonist, the article draws methodological inspiration from biographical ethnography, which encourages the collaborative production of analysis by researcher and researched in a 'polyphonic' way' (Niehaus 2012: 18, cited Wroe 2015: 11). John Chernoff (2003) argues that storytelling can be a more revealing analytical tool than conventional ethnographic analyses insofar as it amplifies the interpretations of the 'storyteller' relative to the researcher. In line with this approach, I (Monteith) sought to establish a process through which both researcher and participant 'respect and value each other's contribution and in that regard are equal in their dialogical relationship' (Schrijvers 1991: 169, cited Van Stapele 2014: 14). George agreed to be listed as a co-author (under a pseudonym) in line with recent moves to co-authorship that challenge the idea of ethnographers as "individuated "sole authors" (Back and Sinha 2018: 173). The story was co-constructed between George and me over the course of several meetings and phone conversations, after which George provided detailed feedback on a written draft. It is the product of various acts of translation: between different languages (Luganda and English), forms (oral testimony and ethnographic prose) and domains (Nairobi's hustle economy and UK academia). The final narrative is thus inevitably partial and open to re-interpretation.

The following sections present this story in three acts. This format acknowledges the narrative form through which George articulated his experiences in Kampala and Nairobi, and the dramatic arc of the 'hustle' as it is experienced by many young men and women in urban East Africa. All names have been anonymised.

\section{ACT 1: Moneylending in Kampala}

At the time of our first meeting in 2013, George was the proprietor of House of Faith, an informal savings and moneylending business with over 500 customers in Nakasero market, one of the largest marketplaces in Kampala, Uganda. George's customers deposited relatively small amounts of money (USh 5,000 / US\$ 1.35) with him on a daily basis, which they then withdrew in full - minus a small service charge 2 - at the end of each month. Rather than providing goods or services from a particular space in the market, he made a living on the move, greeting people by their stalls before taking small amounts of money from them and making an entry in his accounts book. George's phone rang constantly as people pushed shillings into his hand (deposit) or pulled them from it (withdrawal). His nickname at the time was Mutebile, then the Governor of the Bank of Uganda, who was renowned both for his political nous and his alleged role in a number of high-profile financial scams.

George grew up in Katwe, a low-income settlement south of Kampala city centre - a 'difficult place' that taught him how to handle 'difficult characters'.3 His mother followed his grandmother into the market, and George soon after her. The sudden death of George's mother in 2004 marked the end of his formal schooling and the start of his life in Nakasero. When describing his work in the market, he often draws upon a language of 'service' rather than business: service to his family, to his people in the market, and to God. He started attending Revival and Salvation Apostolic Church just prior to his mother's death and married his wife Betty there in 2010. George and Betty rented a two-room house in Katwe, which they subsequently shared with their two sons.

House of Faith essentially socialised people's obligations to save money in the market, enabling people to earmark money for major expenses, such as school fees, while protecting it from the claims of creditors, neighbours and spouses (Monteith 2018). When it was operating 
well, George could expect to earn as much as USh 800,000 (US\$217) from monthly interest payments and service charges. However, great care was required in order to ensure that all of his depositors did not seek to withdraw their savings at the same time. Consequently, George developed an array of indirect modes of avoidance and refusal. For example, when a person requested an unserviceable withdrawal, he would evade particular areas of the market, deliver sermons on the importance of saving, or avoid the market altogether (Ibid.).

The history of informal moneylending in Nakasero is punctuated with betrayals and disappointments which had facilitated the expulsion of previous lenders:

'People who are doing this business are many, for example; Mityana first took their money, then a second time they gave their money to him, now he disappeared completely... Another person came, they gave them the money, [then] he went with people's money. Someone will come and tell them "I save people's money..." They say, "won't you steal our money? No - okay, let me start with USh 100,000"... You know, people here are funny, they can chase you away one minute and then give you their savings the next... They are looking for people to help them but as I told you, we disappoint them.'

February 2014

George's testimony - which was prophetic of the future of his own business in the city - raises the question of how 'trust' is (re)produced in urban settings characterised by duplicity and insecurity, and why people continue to trust in the face of deception. One of the paradoxes of the 'hustle' in dense and competitive urban economies such as Kampala is that the less trust appears to be in evidence in a particular setting, the more people are required to trust, even if this trust is often contingent and fleeting. The decision of people in Nakasero market to continue saving their money with informal moneylenders demonstrated a pragmatic ability to 'make do' by investing in a social infrastructure on which they may come to depend.

Within this context, the business of moneylending was itself dependant on various precarious balances and 'double moves'. George explained:

'It is illegal, the government can never allow me to get people's deposits, and I don't have money to make it legal... They told me to pay one million [US\$260] for a lawyer to start, then one million to register as a limited company... Without this it is a big risk. I'm using a personal account. I involved my brother in this business and I became scared that when I get a problem, he may suffer because you know I'm a human being I can die, so when I die, I don't want him to suffer, so he has access to my account.'

February 2014

The cost of legalisation in Uganda effectively excluded George and his colleagues in Kampala, contributing to the growth of a shadow financial sector. House of Faith's visibility in Nakasero market frequently made it a target for theft. Between 2007-2014, George's business lost approximately USh 10 million (US\$2,592) to robberies that took place as George or his brother made their way between the bank and the market. In addition to this, some of the business's largest debtors fled the country. George resolved these incidents by taking out personal loans from formal financial institutions - using a family land title as collateral - in order to settle his most pressing debts, while reassuring other clients that he would pay back their savings over time. In this sense, the survival of his business was dependant on his ability to bridge the 'double' worlds of finance in Kampala.

Would-be moneylenders must decide how much risk and reward to share with members of their family. On 1 February 2016, George's brother Benjamin went missing from the market. Rumours quickly surfaced that he had withdrawn USh 25 million (US\$6,480) from George's 
account - the sum total of people's savings in the market - and fled the country. After fortyeight hours of searching for his brother across Kampala, George called me:

"I trust God in everything that happens in life but this is too much for me... I can't stop asking myself why. Am I stupid somehow? Was I wrong to trust my family? Is this how human beings are?... Some people feel sorry for me and believe me, others are hunting me; even checking at my house to see if I'm there."

February 2016

Unable to secure a loan to cover the size of the loss, George became wary of his safety in Kampala. Unlike previous losses, the repercussions of this event affected his entire customer base, including senior members of the market leadership who had been implicated in the death of another moneylender in 2012.4 After talking with Betty, he made a series of phone calls to acquaintances residing outside of Uganda, demonstrating a sense of 'preparedness' that is a characteristic of urban inhabitants across the continent (Simone 2001: 18). One of these calls was to Jimmy Nsibambi, a former butcher and friend in the market who had fled the country a year earlier in the face of mounting debt (including an unpaid loan of USh 800,000 to House of Faith). George tracked Jimmy down via his wife in Kampala - herself a former vendor in Nakasero - and discovered that he was living in Nairobi. George packed his belongings and boarded a bus to Kenya, becoming one of a growing number of transnational migrants fleeing debt on the continent. Betty decided to stay in Kampala in order not to 'disturb' the schooling of their two children on the understanding that George would return home as soon as he had raised enough money to appease his most significant creditors.

\section{ACT 2: Storytelling in Nairobi}

On arrival in Nairobi, George was reunited with a number of former acquaintances who had themselves left Uganda in order to escape debts of various kinds. He accepted Jimmy's invitation to share a rented room in Kawangware - a low-income settlement five kilometres west of downtown Nairobi - with four other young men from Uganda, including Ivan, an extrader from Nakasero who also had an outstanding loan with House of Faith. George explained:

'Reaching Nairobi I found these brothers of mine from Kampala; I found [Jimmy] and [Ivan], who I was working with in Nakasero and I thought had gone to Dubai... You know, they never told us [that they were in Nairobi]. Even though they ran away with money, I had to act like everything was normal: "Oh hi! You're here? How are you, man? What's up?" That is acting; you feel bad, but you have to pretend that the situation is OK... I didn't think of discussing it with them because I had no time and it wasn't necessary when I had a lot in my head.'

February 2016

It is common for young men and women to hide their plans for onward migration even from their closest friends and family, as a result of a fear that these plans may be sabotaged (Bakewell and Landau 2018). However once abroad, many of my Ugandan friends projected a narrative of successful migration by pretending to be in the UK, the USA and Dubai (rather than Kenya, Tanzania and South Africa); a 'bluff' through which they sought to 'absorb modernity through contact with otherness' in the form of geographic space (Newell 2012: 31). Rather than calling out Ivan's bluff, George decided to act 'like everything was normal'. He explained: 'it is impossible to know the situation and the reasons why a person did something', and besides, this understanding 'wasn't necessary' for the purposes of his life in Nairobi at the time (indeed, asking too many questions may have endangered his hospitality). In this way, the loans issued by George in Kampala arguably served as a sort of social investment through which he was able to acquire future dependants and obligations (described elsewhere as the attainment of 'wealth in people' - see Guyer 1993). 
Jimmy and Ivan each reportedly contributed KES 3,700 (US\$36) to George's rent and upkeep and agreed to host him for a month. One of George's first tasks was to arrange a Kenyan bank account and sim card in order to exchange news and resources with friends and family in Kampala. He explained:

'Life in Kenya is harder. I'm like in hibernation - I'm not yet paid and I'm completely broke and I don't want to stress [Betty] because she also has a lot to take care of... I'm lucky that this friend is paying rent so I just have to find money for food and transport.'

February 2016

However, George found opportunities for income-generation hard to come by. Transnational migrants are unable to work legally in Nairobi without the appropriate visas, which themselves require time and money. There are strict limitations on the total number migrant workers in Kenya and documented and undocumented migrants routinely experience harassment from Kenyan security services (Campbell 2006). In addition, the language of street trade in Nairobi is Sheng, an urban slang language combining Swahili, English and other Kenyan languages (Samper 2002). Thus, while visa regulations limited George's entry into the formal sectors of Nairobi's economy, language restrictions limited his entry into their informal counterparts. His use of the metaphor of 'hibernation' evokes a resultant sense of dormancy or 'waithood'; suspended between Nairobi and the site of an as-yet-undefined future. After a month in Kenya, George declared: 'I don't know what to do in this country, I don't have any money; even the person helping me is starting to see me as a burden'. In need of an income, George was introduced to a new opportunity by his housemates in Kawangware.

One of the most contentious political issues in Uganda prior to George's departure was the anti-homosexuality bill, which sought to expand and intensify the criminalisation of same-sex relationships.5 Following sustained international media coverage of the bill, UNHCR prioritised the resettlement of LGBT refugees, and Kenya accepted 400 such cases by 2014, providing them with financial assistance in Nairobi while they applied for formal resettlement (ORAM 2014).6 It was in this context that George sent me the following message in March 2016:

I'm going to UN for help and these guys listen to people with gay issues mostly, but as per now I need their help here in Kenya... I have to give them a story as to why I want them to help me William... And it's going to be about my family harassing me and destroying my business because I have you as my friend and they think we are gay... And you're not a gay but because you're a Westerner they think you are a gay and they think I'm going to start gay things in society.'

March 2016

This request brought into sharp relief the ethical dimension of the relationship between George and me (researcher and interlocutor), as well as the ways in which both the research and humanitarian sectors have become part of the extended landscape of the hustle economy. For George, accessing support via the UN refugee agency was seen to require the performance of a particular speech act - or 'story' - in much the same way as working in the film industry. In this case, the story had to be of a sufficiently dramatic nature so as to justify a person leaving their country of origin, and to include other parties whose testimonies could attest to its veracity. The potential value of this story was an indefinite monthly payment of KES 6,000 (US\$60) and the opportunity for resettlement. I was eager to support George but reluctant to provide a false testimony on account of a concern for both the situation of legitimate sexual refugees in Kenya and my own (comfortable) job and life in the UK. An official request never arrived. 
All five of George's Ugandan housemates in Kawangware had lodged similar appeals, in spite of the fact that none of them identified as homosexual. Indeed, the group spent considerable time at home discussing and refining their respective stories. Ivan created a backstory that involved him living a flamboyant 'homosexual lifestyle' in one of Kampala's largest low-income settlements, only for the others to point out that this was a story 'no one was going to believe'. UNHCR confiscated George's personal effects (phones, notebooks, etc.) and asked him to recount his story in detail with a focus on specific names, places and dates. He was then told that he would be required to return twelve months later to recount the same story ('they always trick you like that'). Having gone through the same process, George's housemates advised him to base his story on 'something that is real' - in this case, a request made to George by a colleague in Kampala that he stop associating with me at the time of the passing of the antihomosexuality bill.

Once constructed, these stories had to be enacted. The refugee agency required that all five of the men attend victim support meetings with other Ugandans in Nairobi. George immediately recognised some of the other attendees from his business dealings in Kampala: 'It was very difficult to pretend! Everyone had to raise challenges.' Such performances extended to wide-reaching aspects of their lives in Nairobi, including their gendered living arrangements. George explained, 'Girls live with girls to pretend [to be] lesbians and men live with men to pretend [to be] gay... you have to convince these people; they have to believe.' As a result of these arrangements, Ivan lived separately from his wife and child in Kawangware.

The hustle emerges here as an improvised mode of income generation involving the production and enactment of a specific role to a particular audience (UNHCR) in the hope of a financial return. In order to succeed, this process was dependant on skilful acts of translation through which fragments of the men's 'real' lives were carefully incorporated into their roles. Rarely during this period did George express concern about the ethics of the performance, or the gap between the 'real' and the imaginary. Rather, like the 'modernity bluff' described by Newell, there was an underlying understanding that if the performance works it is valid; 'only upon discovery does it become fake' (2012: 261). In this way, the men's performances had the capacity to 'conjoin the real and imaginary, illusion and authenticity' (Ibid.: 21). Unlike the improvised, momentary performances associated with the street-hustle, this performance was long-term and permeated into all areas of their lives. Indeed, George expressed a concern that some Ugandans had 'become gay' as a result of the process.

The expansion of refugee economies into African cities has facilitated the involvement of a diverse range of actors and institutions in the resettlement process. Lauterbach (2014) has written of the role of Pentecostal churches in Kampala in preparing Congolese refugees for the resettlement process, including the provision of guidance on how to articulate their stories in such a way that they will be taken seriously by NGOs and humanitarian agencies. The humanitarian industry in Africa might therefore be thought of a system of 'doubles' (Mbembe 2001). In order to access formal assistance, asylum seekers must become adept at translating complex and distressing fragments of their lived experience into a narrative that satisfies the bureaucratic conditionalities of humanitarian agencies.

Like thousands of others, George also turned to Pentecostalism for assistance in Nairobi. One of the other calls that he made prior to boarding the bus to Nairobi was to a pastor at his local church. He explained: 'I had pastors in Uganda telling me to go to certain churches in Kenya saying, 'go to this pastor he will receive you, go to that pastor he will receive you...' However, George discovered that most pastors in Nairobi communicate in Kikuyu and/or Swahili; languages with which he was not yet familiar. Sarah, a Kenyan neighbour, invited George to an English Pentecostal service in Kilimani after hearing him singing gospel songs in Kawangware. He reflected: 'I was looking for a connection with God but also for friends to advise me and strengthen me; to give me peace and hope'. George's new congregation 
provided him with assistance and 'inspiration', alongside ad hoc contributions to his upkeep. Such forms of assistance enabled him to contribute to the all-male household in Kawangware while he waited for support from UNHCR. He explained: 'it was one hundred per cent how I survived in Kenya... most of the people helped me because of my faith.'

Landau (2010: 326) has described Pentecostal Christianity as 'perhaps the most powerful mode of transcendent belonging' in sub-Saharan Africa; effective at both overcoming barriers within migrants' place of residence while preparing them for a life elsewhere. However, George's identity as a born-again Christian in Nairobi soon came into conflict with the identity he was performing in the offices of UNHCR:

"I couldn't live in the church at the same time as doing the other [refugee] process... it's hard to be Ugandan and a refugee in Kenya because there is no war in Uganda, and people ask, 'you are seeking asylum for what?' So I couldn't go to the church and at the same time be part of a gay family..."

December 2017

George's identities in Nairobi as a born-again pastor and a homosexual asylum seeker thus required careful management. For a number of months, his economic survival was dependant on the maintenance of a double-life between the refugee agency and the church. At church services in Kilimani, George wore a dark button-down shirt with black trousers and leather shoes and spoke excitedly; at refugee meetings in Kawangware, he wore brightly coloured tshirts and shorts (leant to him by his housemates) and spoke solemnly. In this way, he came to designate 'specific places and domains for being specific things, working out contradictory needs and aspirations' (Simone 2001: 21). However, the threat of discovery and the crosscontamination of his double-life meant that George spent an increasing amount of time confined to his shared room in Kawangware while awaiting the outcome of his case. He worked hard to ensure that none of his neighbours saw him travel to UNHCR, describing this period as 'tiresome' and 'confusing'; 'you can't imagine how I sleep'.

Scholars have deployed the concept of 'straddling' to describe situations in which people maintain different livelihood strategies in different places (Bayart 1993; Cowen and Kinyanjui 1977; Englund 2002). However, the concept has been critiqued for reifying particular identities and domains (e.g. the rural farmer and the urban taxi driver), rather than revealing the continuities and tensions that lie between them (Englund 2002). In contrast, the concept of translation foregrounds the relational aspect of different socioeconomic identities and the ways in which these identities are converted between different domains. As an asylum seeker and born-again Christian in Nairobi, George both was and was no longer himself - taking up a liminal position between his past life in Kampala and his future life elsewhere. This sense of liminality is illustrative of the tension between action and constraint, movement and 'stuckness' within the broader terrain of the hustle. Each of George's roles in Nairobi presented the promise of a future life. However, their interaction generated a friction that served as a constraint on his mental health and mobility.

In response, George looked for solace in a third, digital domain. In August 2016, he and Ivan purchased a second-hand laptop from a member of his congregation, explaining: 'at least now I can watch movies and live [Premier League] matches on Facebook while looking for some online business.' He began to make regular social media posts, sharing pictures of his wife and children, extracts from sermons ('may God strengthen us all to make the world a better place for others'), and depictions of a persona that he termed 'bling bling' George (images of George dressed in football shirts emblazoned with the logos of global brands). In this way, he arguably performed his own version of the 'modernity bluff' in order to mobilise friends and colleagues in Kampala (Newell 2012). Some responded by demanding that George reveal his location and repay the money owed to them by House of Faith. However, others consoled him about his brother's betrayal and wished him well. He reflected on this period of online activity: 
'I feel a bit alive; I'm at least in some people's hearts... the problems are still there, but life is somehow good'.

George's activities during this period arguably resembled an attempt to 'hedge one's bets' through a series of improvised engagements with different associations and domains (Gotz \& Simone 2003). These engagements involved creative acts of deception and circumvention ('I have to give them a story...') and subversions of authority that are characteristic of the hustle. However, they also produced a number of tensions; for example, between George's double identity as a homosexual asylum seeker and a Pentecostal subject, which left him 'stuck' in both a literal and a figurative sense. Rather than resolving these tensions, George sought to work through them through engagements with other forms of belonging located within the diasporic domain of family, the global domain of fashion, and the transcendent domain of Pentecostalism. However, missing from these engagements was a commitment to the types of place-based politics and associations that are generative of urban life (Thieme et al., this issue). Consequently, George's activities might be said to represent a form of uprooted hustle that sought to overcome the immediate constraints of life in Nairobi while aspiring to a life elsewhere (Landau \& Haupt 2007: 10).

By the end of 2016, UNCHR began to scale back its operations in Nairobi in response to a government policy to reduce the number of urban refugees in the country (ENCA 2016). George explained: 'they are making it hard for people'. After two monthly payments of KES $6,000$ (US $\$ 60)$, George was told that the he would receive no further assistance. He thus began to look for new opportunities.

\section{ACT 3: Dubbing in Nairobi outskirts}

During his search for a laptop, George explained to me that portable electronic devices are generally cheaper in Nairobi than Kampala due to their closer proximity to the port at Mombasa. He and Ivan reached out to some of their more sympathetic former colleagues in Nakasero to sound out interest in a new business venture. They discovered that fish maws (dehydrated fish bladders) had become in high demand in Kampala owing to an influx of buyers exporting them for Chinese medicine. George sought out suppliers on Lake Victoria through his congregation in Kilimani and accepted orders from Kampala via mobile money. $\mathrm{He}$ and Ivan began to smuggle smartphones, fish maws and beads (for Betty's business) across the border. It was with reference to these journeys that the 'hustle' appeared as an emic term in George's story:

'That's the hustle, that's the hustle. You have to use each and every trick you know to pass through the border... for example, using small bags - no one can expect to have goods in that kind of bag... people here know that crossing the border is business. There are some specialists there to help you cross borders. But it's not $100 \%$; like this week I was caught by URA [Uganda Revenue Authority] when waiting for my friend to pick me up. URA knows that around the border it's business! It's deals. If they find you they have to question you about your luggage... They asked, "Where are the licenses? Where are the papers?" I told them I don't have them. They said, "We are taking you back so that you can pay a fine and clear them at the border". I said, "No - we can discuss about it". They said, "What are you saying?" I told them "I'm going to pay you 100,000". They said, "No, this is little - we need 500,000 ". I said "What!?" But I had to pay... They said, "Next time don't just cross like that - call us and we'll help you."'

June 2016

George's interaction with the URA officers was illustrative of the existence of a world of 'doubles', in which there is a 'lack of correspondence' between what one sees and exposes', and the real value of things' (Mbembe 2001: 148). Upon his apprehension, George performed the role of the naive merchant and the revenue officers that of officious state functionary. And 
yet, all the while, a separate negotiation was taking place. The terms of this negotiation were shaped both by the formal customs laws of Uganda - including the legal punishment for smuggling - and the informal particularities of George's situation - including the current market value of his goods and the amount of money that he could reasonably be expected to raise at short notice. While the URA officials held the advantage in the former domain, George had the advantage in the latter. The negotiation thus required both parties to participate in performative acts of conversion without losing their cultural footing (Simone \& Pieterse 2017: 155). George reflected that the final price in this particular negotiation (USh 500,000 ) was 'fair'. He made a call to a buyer in Kampala and transferred the funds via mobile money.7

One of the advantages of George's cross-border activities was that he was able to spend more time with his family, who would regularly meet him at the border. The money he was generating from smuggling fish maws enabled him to make a substantial contribution to his household for the first time since leaving Kampala. However, Betty had become invested in the idea of resettlement during the early stages of George's UNCHR case and was disappointed that George had chosen to remain in Nairobi following its conclusion. George explained that he could now make more money in Nairobi, and that he would need this money in order to return home safely by appeasing his largest creditors. Wary that some of Betty's friends were advising her to leave him, he made a series of social media posts in which he praised her for providing for their children 'like a father and a mother' and pledged to return and give her what she 'deserves'. In spite of his frequent movements across the border, George remained 'stuck' in a broader sense; unable to return to his home and family in Kampala and unwilling to put down roots in Nairobi.

In June 2016, Ivan received a phone call from a Ugandan friend in Nairobi asking if he knew any Luganda speakers who would be willing to dub a Chinese film prior to its release in Uganda. Chinese multimedia companies were attempting to break into the Ugandan market and Ugandan voice actors were in such high demand in Kenya that companies were willing to pay a finder's fee to those able to supply them. George accepted to undertake this work alongside Ivan, Jimmy and his two other housemates. They travelled together via matatu to the studio of one of Nairobi's largest dubbing companies in Karen, a part of the city 'where rich gangs live'. On arrival, they met another fifteen Ugandans, including another former customer of House of Faith in Kampala. A director asked the group for proof of their right to work in Kenya and informed them that they would receive 15 KES (US\$0.15) for each line they recorded. George and his colleagues explained that their work visas were still being processed (they made no mention of their asylum applications) and were quickly put to work. He explained:

'It's called dubbing, it's where a Chinese movie is done and we remove the Chinese language and fix a certain language - English or Luganda - through lip-syncing, and they fix it in the studio... You have to fit in; you have to understand the movie so that you act exactly like the [original] actor.'

June 2017

For four months, George and his colleagues travelled to the studio in Karen for intensive threeweek recording stints during which they dubbed films from China ('Chinawood') and Bollywood. These included action films ('Over the Moon'), horror ('Black Evil') and family comedies ('Hey Daddy'). Once complete, the audio tracks were sent to China for approval and distributed in Uganda. The actors could each expect to receive around 50,000 KES (US\$500) for a completed film. However, each film took three to four weeks to dub, and the approval process often extended over several months. George explained, 'it was supposed to take two weeks [to get paid] but it took two months... two months without paying us.'

Payment was further delayed by the fact that the dubbing company required all of its employees to set up a Kenyan bank account in order to receive funds. After a few months, 
two of the Kenyan directors approached the Ugandan cast outside the studio to ask whether they would be interested in establishing a new company in which they would be paid $20 \mathrm{KES}$ (US\$0.20) per line, in cash. Eight of them agreed - including George and his four housemates - thus making a shift into Nairobi's burgeoning shadow dub economy. The directors of the new company rented a studio space in Syokimau, twelve kilometres from Nairobi city centre. The cheapest slots were available at night, and so for several months, George and his colleagues made the long journey from Kawangware to Syokimau late in the evening via three matatu rides, before transforming themselves into heroes and anti-heroes imagined in Shanghai and Hong Kong. The cover of night provided a certain distance from Kenyan tax authorities ('we work undercover; the company keeps it a secret'). 8

George and his colleagues enjoyed new levels of responsibility in the new company and reportedly felt like 'brothers'. However, getting paid was no easier than before. He explained that the two directors 'tricked' the Ugandan actors by editing the script in order to reduce their number of lines - for example by fusing different lines of dialogue together - therefore reducing their pay. In addition to this, the company also delayed payment for several weeks pending the approval of the Chinese media conglomerate. In this way, George fell victim to similar forms of deception and circumvention to that which he had deployed during other pursuits in Nairobi. Socioeconomic advancement for George - as for film producers and state officials was dependent on performative acts of duplicity, subterfuge and pretence, thus eroding the boundaries between the studio and the city.

\section{Conclusions}

The Nairobi experienced by George was a fleeting and transient city that provided a certain idea of redemption during a difficult period in his life. It is a city in which it is possible to reinvent oneself multiple times, and in which performing the right role at the right time can provide access to new and potentially lucrative opportunities. Success thus requires a capacity to read between the lines and to navigate seemingly contradictory worlds without losing one's footing. I have argued that young men demonstrate this capacity through translational practices of acting and storytelling. Such practices foreground the relational aspect of different socioeconomic identities, the ways in which these identities are converted between different domains. Through such activities, men such as George could be said to demonstrate a counter-intuitive capacity to 'thrive amid frictions' (Simone \& Pieterse 2017: 155). Yet George did not thrive amid the frictions produced by his double-life in Nairobi. In spite of generating modest financial rewards, these frictions often acted as a constraint on his mobility, generating a sense of isolation and confusion as the lines blurred between the 'real' and the imaginary.

The conceptual frame of the 'hustle' foregrounds the ways in which such acts of improvisation are grounded in broader systems of association and belonging that are generative of particular forms of urban life. George made sense of his activities in Nairobi with reference to three particular social domains: his household in Kawangware, his congregation in Kilimani and (particularly) his family in Kampala. While George's household and church provided important forms of material and spiritual assistance and association at critical junctures, he survived his most difficult moments by maintaining a (virtual) connection to his friends and family in Kampala. However, none of these three domains were generative of forms of belonging rooted in Nairobi. Instead, his family provided a sense of belonging rooted in Kampala, his church a form of spiritual belonging that transcended Nairobi, and his household a temporary form of belonging that was underwritten by the promise of exit. Such diverse and distant forms of association can have 'disintegrating effects' insofar as they dilute the collective efforts and affiliations necessary to achieve long-term change in particular contexts (Gotz \& Simone 2003: 126). Rather than a hustle that is generative of social and political compositions rooted within Nairobi then, transnational migrants such as George arguably participate in a form of uprooted hustle that is oriented towards individual survival and exit (Landau \& Haupt 2007). 
George's interactions with humanitarian agencies, border regimes and film companies are illustrative of the ways in which the tactics of the hustle move across social domains, infiltrating large institutions and industries. For example, he drew upon a similar language of tricksterism to describe the logics of Nairobi's shadow film industry and the UN refugee agency. Whether in the market, at the border or in the studio, 'you act... according to the situation you are in'. As one curtain falls another one rises, providing a stage on which to perform the next role and walk the line between redemption and ruination. 


\section{Notes}

1 For example, the the entertainment and media sector in Kenya is predicted to grow at an annual rate of approximately $8 \%$ between $2015-2020$, compared to $4 \%$ for the world as a whole (Global Entertainment and Media Outlook 2016-2020, PwC, Ovum)

2 This charge is between USh $1,000-10,000$, depending on the total amount saved.

3 The settlement was depicted in the 2016 Disney film 'Queen of Katwe', based on the childhood of Phiona Mutesi, Uganda's foremost chess player.

4 New Vision (2012) 'City market bosses held over murder,' 19 April

5 The bill was drafted in 2009, passed into law in February 2014 and then overturned by the constitutional court in August 2014. It sparked a wide-reaching public debate, heavily influenced by politicians and religious leaders, who sought to equate homosexuality with a form of social and moral crisis (Boyd 2014; Sadgrove et al. 2012).

6 The lack of an official category for LGBT refugees makes it difficult to identify how many have been resettled to avoid persecution due to their sexual orientation.

7 Informal cross-border trade has a long history in East Africa involving both engagement with state officials and integration into local communities (Asiimwe 2013; Titeca 2012). Amin's rule in the 1970s became synonymous with the rise of the magendo (or 'black economy') in Uganda through which sugar and cigarettes, among other luxury items, were smuggled across the Kenyan-Ugandan border as part of a broader system of 'highly risky, unpredictable and costly operations' (Asiimwe 2013: 117).

${ }_{8}$ One of the first films translated for the new company was entitled 'Super Pattern', which tells the story of a retired Chinese military veteran Guo Youdong (voiced by George), who adopts a stray dog which turns out to be the last descendant of a breed of geneticallyenhanced canines bred for their strength and intelligence. Ivan recorded the Video Joker (VJ) track for the film, guiding Ugandan audiences through key plot developments through shouts of 'fight!' (okulwaana) and 'action!'.

\section{Acknowledgements}

This article was made possible by the friendship and generosity of the people of Nakasero market. Thank you to Laura Camfield, Ben Jones, Tatiana Thieme, Meghan Ference, Naomi van Stapele, Maxim Bolt and the reviewers for their helpful comments and encouragement. All shortcomings remain my own. 


\section{References}

Agamben, G. (1993) Coming Community (Theory Out Of Bounds). Minnesota: University Of Minnesota Press

Asiimwe, G. B. (2013) 'From Monopoly Marketing to Coffee Magendo: Responses to Policy Recklessness and Extraction in Uganda, 1971-79.' Journal of Eastern African Studies 7 (1): 104-24.

Back, L, and S. Sinha (2018) Migrant City. London: Routledge.

Bakewell, O. and G. Jónsson (2011) 'Migration, Mobility and the African City.' IMI Working Papers, no. 50: 1-31.

Bakewell, O. and L. B. Landau (2018) Forging African Communities: Mobility, Integration and Belonging. Basingstoke: Palgrave Macmillan.

Batterbury, S. (2001) 'Of Diversity : A Local Political Ecology of Livelihood Diversification in South-Western Niger.' Ecumene 8 (4).

Bayart, J.F. (1993) The State in Africa: The Politics of the Belly. 1st ed. Cambridge ; Malden, MA: Polity.

Bjarnesen, J. and M. Utas (2018) 'Introduction Urban Kinship: The Micro-Politics of Proximity and Relatedness in African Cities.' Africa 88 (S1): 1-11.

Boyd, L. (2014) 'The Problem with Freedom: Homosexuality and Human Rights in Uganda.' Anthropological Quarterly 86 (3): 697-724.

Campbell, E. H. (2006) 'Urban refugees in Nairobi: Problems of protection, mechanisms of survival, and possibilities for integration.' Journal of Refugee Studies 19 (3): 396-413

Chernoff, J. (2003) Hustling Is Not Stealing: Stories of an African Bar Girl. Chicago: University of Chicago Press.

Cliggett, L. (2005) 'Remitting the Gift: Zambian Mobility and Anthropological Insights for Migration Studies.' Population, Space and Place 11 (1): 35-48.

Comaroff, J. and J. Comaroff (2003) 'Ethnography on an Awkward Scale: Postcolonial Anthropology and the Violence of Abstraction.' Ethnography 4 (2): 147-179

Cooper, E. and D. Pratten (2014) Ethnographies of Uncertainty in Africa. Basingstoke: Palgrave Macmillan.

Cowen, M. P. and K. Kinyanjui (1977) 'Some Problems of Capital and Class in Kenya.' University of Nairobi Institute of Development Studies Occasional Paper, no. 26

De Boeck, F. and Plissart, M. F. (2004). Kinshasa: Tales of the Invisible City. Tervuren and Ludion: Royal Museum of Central Africa and Vlaams Architectuureninstituut Vai.

Di Nunzio, M. (2019) The Act of Living: Street Life, Marginality, and Development in Urban Ethiopia, Ithaca: Cornell University Press.

Duneier, M. Kasinitz, P. and A. Murphy (2014) 'Ethnographers and Their Subjects.' In The Urban Ethnography Reader, 767-72. New York: Oxford University Press.

ENCA (2016) 'Refugees in urban areas must also leave, says Kenya government', 21 June (https://www.enca.com/africa/refugees-in-urban-areas-must-also-leave-says-kenyagovernment, accessed on 01/08/2018).

Englund, H. (2002) 'The Village in the City, the City in the Village: Migrants in Lilongwe.' Journal of Southern African Studies 28 (April 2015): 137-54.

Ferguson, J. (2006) Global Shadows : Africa in the Neoliberal World Order. Durham N.C.: Duke University Press.

Gabay, C. (2018) Imagining Africa: Whiteness and the Western Gaze, Cambridge: Cambridge University Press 
Gotz, G., and A.M. Simone (2003) 'On Belonging and Becoming in African Cities.' In Emerging Johannesburg: Perspectives on the Postapartheid City, edited by R. Beauregard, L. Bremmer, and X. Mangcu, 123-47. London: Routledge.

Green, R. (1981) 'Magendo in the Political Economy of Uganda. Pathology, Parallel System. or Dominant Sub-Mode of Production.' Institute of Development Studies Discussion Paper Series (No. 164).

Guyer, J. I. (1993) 'Wealth in People and Self-Realization in Equatorial Africa', Man 28 (2): 243-265.

Guyer, J. I. (2004) Marginal Gains: Monetary Transactions in Atlantic Africa. London; Chicago: University of Chicago Press.

Honwana, A., and F. De Boeck. (2005) Makers and Breakers: Children and Youth in Postcolonial Africa. Oxford: James Currey.

Honwana, A. M. (2012) 'The Time of Youth: Work, Social Change, and Politics in Africa.' The Time of Youth: Work, Social Change, and Politics in Africa 39 (3): 554-57.

James, D. (2014) Money from Nothing: Indebtedness and Aspiration in South Africa. Palo Alto: Stanford University Press.

Jones, J. L. (2010) "'Nothing Is Straight in Zimbabwe': The Rise of the Kukiya-Kiya Economy 2000-2008.' Journal of Southern African Studies 36 (2): 285-99.

Landau, L. B. (2006) 'Transplants and Transients: Idioms of Belonging and Dislocation in Inner-City Johannesburg.' African Studies Review 49 (2): 125-45.

Landau, L B. (2010) 'Passage, profit, protection and the challenge of participation.' WIDER Working Paper, No. 2010/49, The United Nations University World Institute for Development Economics Research (UNU-WIDER), Helsinki

Landau, L. B, and I. Haupt (2007) 'Tactical Cosmopolitanism and Idioms of Belonging: Insertion and Self-Exclusion in Johannesburg.' Migration Studies Working Paper Series \#32.

Lauterbach, K. (2014) 'Religion and Displacement in Africa.' Religion and Theology 21 (3-4): 290-308.

Lund, C. (2014) 'The Ethics of Fruitful Misunderstanding'. Journal of Research Practice, 10(2), 53-55.

MacGaffey, J. (1991) The Real Economy of Zaire: The Contribution of Smuggling \& Other Unofficial Activities to National Wealth. London: James Currey.

Mains, D. (2007) 'Neoliberal Times: Progress, Boredom, and Shame among Young Men in Urban Ethiopia.' American Ethnologist 34 (4): 659-73.

Mbembe, A. and J. Roitman (1995) 'Figures of the Subject in Times of Crisis.' Public Culture 7 (2): 323-52.

Mbembé, J. A. (2001) On the Postcolony. Berkeley: University of California Press.

Monteith, W. (2017) 'Showing 'Heart' through Ethnography.' City 21 (2): 178-89.

Monteith, W. (2018) 'Showing 'heart' while making money: Negotiating proximity in a Ugandan marketplace.' Africa 88 (S1): 12-30.

Newell, S. (2012) The Modernity Bluff : Crime, Consumption, and Citizenship in Côte d'Ivoire. London.

Niehaus, I. (2012) Witchcraft and a Life in the New South Africa. Cambridge: Cambridge University Press.

ORAM. 2014. 'Country of Origin Report: Sexual and Gender Minorities. Organization for Refuge, Asylum \& Migration (https://www.refworld.org/docid/54588abc4.html, accesssed 01/08/2019) 
Oxford English Dictionary (2000) Oxford English Dictionary (3rd Ed), Oxford: Oxford University Press

Parnell, S. and J. Robinson (2012) '(Re)Theorizing Cities from the Global South: Looking Beyond Neoliberalism.' Urban Geography 33 (4): 593-617.

Porter, G., K. Hampshire, A. Abane, A. Munthali, E. Robson, A. Tanle, S. Owusu, A. De Lannoy, and A. Bango (2018) 'Connecting with Home, Keeping in Touch: Physical and Virtual Mobility across Stretched Families in Sub-Saharan Africa.' Africa 88 (2): 404-24.

Porter, G., K. Hampshire, A. Abane, E. Robson, A. Munthali, M. Mashiri and A. Tanle (2010) 'Moving Young Lives: Mobility, Immobility and Inter-Generational Tensions in Urban Africa.' Geoforum 41 (5): 796-804.

Potts, D. (2011) 'Making a Livelihood in (and beyond) the African City: The Experience of Zimbabwe.' Africa 81 (4): 588-605.

Prunier, G. (1983) 'Le magendo: Essai sur quelques aspects marginaux des échanges commerciaux en Afrique orientale.' Politique Africaine, 9, 53- 62.

Roitman, J.L. (1990) 'The Politics of Informal Markets in Sub-Saharan Africa.' Journal of Modern African Studies 28 (4): 671-96.

Sadgrove, J., R. M. Vanderbeck, J. Andersson, G. Valentine, and K. Ward. (2012) 'Morality Plays and Money Matters: Towards a Situated Understanding of the Politics of Homosexuality in Uganda.' Journal of Modern African Studies 50 (1): 103-29.

Schrijvers, J. (1991) 'Dialectics of a Dialogical Ideal: Studying Sideways and Studying Up.' In Constructing Knowledge: Authority and Critique in Social Science, edited by L. Nencel and P. Pels, 162-179. London: Sage.

Schamper, D. I. (2002) 'Talking Sheng: The role of a hybrid language in the construction of identity and youth culture in Nairobi, Kenya.' Unpublished dissertation, University of Pennsylvania Press

Simone, A.M. (2001) 'On the Worlding of African Cities.' African Studies Review 44 (2): 1541.

Simone, A. M. (2004) For the City yet to Come: Changing African Life in Four Cities. Durham N.C.: Duke University Press.

Simone, A. M. and E. Pieterse. (2017) New Urban Worlds: Inhabiting Dissonant Times.

Thieme, T. (2018) 'The Hustle Economy: Informality, Uncertainty and the Geographies of Getting By.' Progress in Human Geography 42 (4): 529-48.

Titeca, K. (2012) 'Tycoons and Contraband: Informal Cross-Border Trade in West Nile, North-Western Uganda.' Journal of Eastern African Studies, no. April 2013: 37-41.

Van Stapele, N. (2014) 'Intersubjectivity, Self-Reflexivity and Agency: Narrating about 'self' and 'Other' in Feminist Research.' Women's Studies International Forum 43: 13-21.

Vigh, H. (2006). Navigating Terrains of War: Youth and Soldiering in Guinea-Bissau. New York: Berghahn.

Weiss, B. (2009) Street Dreams and Hip Hop Barbershops: Global Fantasy in Urban Tanzania. Bloomington: Indiana University Press.

Wroe, D. (2015). "What Can I Do ?' Living with Doubt and Uncertainty in the Central Region of Malawi.' Unpublished PhD thesis, School of International Development, University of East Anglia. 